\section{National Bibliography of Nigeria}

"Niqerian Publications", 1956, the fifth issue of Nigeria's current national bibliography (pp. 39. Ibadan Univ. Press. 10s.), lists all works received under the Publications Ordinance by Ibadan University College Library during January December 1956. These are arranged by author, works in the English language being listed first, followed by separate lists of works in the several vernaculars. There are also lists of new Nigerian periodicals, of changes of title and of those which ceased publication during the year, and finally of recent works on Nigeria and by Nigerians published outside Nigeria. The Librarian notes a sharp drop in the number of works published in Nigeria, from 599 in 1955 to 348 in 1956, half of which are now Government publications compared with 26 per cent in 1955. The vernacular languages, however, are declining ; in 1956 they were responsible for only 9 per cent of the total. Creative writing is almost entirely absent.

\section{Progressive Verticillium Wilt of Hops at Wye College}

As stated in the recently published annual report of the Wye College Department of Hop Research, a single plant in one of the College hop gardens was found in 1956 to be infected with Verticillium albo. atrum. An outbreak of progressive wilt having been treated on the College farm in 1955, this new case was at once suspected to be progressive wilt. The report envisaged the possibility that if this recent diagnosis was also confirmed, Wye College might be forced to accept the status of a 'wilt farm', a step which would raise major issues of policy. During the 1957 season, no further cases of $V$. albo-atrum in hops have been found at Wye, and pathogenicity tests with the fungus from the 1956 case have been carried out by the National Agricultural Advisory Service and by East Malling Research Station. The results of these tests clearly show that this 1956 infection was not progressive wilt but was due to the non-serious or fluctuating strain of the fungus. No case of progressive wilt (caused by the virulent or lethal strain) has therefore been recorded in the College hop gardens for two years and it appears probable that the drastic control measures carried out in 1955 have been successful in suppressing the only known outbreak. In view of this, hop research will continue at $W y e$ without any radical change in policy. Provided no further cases of wilt occur, the College Farm will in a few years be declared officially to be an uninfected area. Meanwhile the present strict regulations prohibiting visits to the gardens and the release of all planting material remain in force.

\section{Agricultural and Forestry Research in East Africa}

MANY interesting lines of work are described in the research report for 1956 issued by the East African Agriculture and Forestry Research Organization. Most of the problems under investigation are of a long-term or inter-territorial nature. This is well illustrated by the three experiments, one in Tanganyika and two in Kenya co-ordinated by the Physies Division, on the effect of changes in land-use in high catchment areas on the evenness of river flows. The factors controlling the rate of decomposition of humus have been studied by the Chemistry Division and their results appear to offer an explanation both of the beneficial effects of burning and also of the nitrate flush at the start of the rains, and it seems likely that these findings may have a fairly general application on other tropical and sub-tropical soils. In the Forestry Division, special attention has been paid to nursery and transplant bed techniques for tho production of exotic softwoods. Considerable success has been obtained and demonstrations of the new methods are being made in the Territories. Measurement of the yield of grasslands has formed an important part of the work in the Animal Industry Division, and it is now realized that the size of the experimental plot needed to achieve a ten per cent coefficient of variation is much larger than was expected. This is due to the seasonal aridity, uniformity of growth comparable with that of temper. ate pastures being found during the rainy season only. In feeding trials with sheep and cattle the total percentage content of crude protein in the fodder proved to be the most important factor determining its digestibility, and a statistical oxamination of the data from all the digestibility trials in East Africa and of many other parts of the world showed this to be true of both temperate and tropical regions.

\section{Tokyo Astronomical Observatory}

Tokyo Astronomical Bulletins issued between January 20 and May 20, 1957, consist mainly of tabular matter relating to observations made at Tokyo Astronomical Observatory. No. 92 does not deal with observations, but is entitled "Some Improvements of Short Wave Receivers for Time Signal Reception"; it describes how frequency-amplitude characteristics of the receivers at 'Tokyo Astronomical Observatory were improved so that there has been a decroase in the delay times and wave-form distortion in order to meet the present methods of registering and request for high accuracy. No. 94, "Scanning Photoelectric Photometer and Method of Observation of Night Airglow for the International Geophysical Year", describes some improvements made in the two sets of scanning photoelectric photometers that have been in use for about four years for the observation of the green line in the night airglow at the Tokyo Observatory.

\section{Fluorescence of Impurities}

When a small quantity (about 1 part in $10^{5}$ ) of tetracene (the 'impurity') is added to anthracene (the matrix) the fluorescence of the anthracene is suppressed and tetracene fluorescence of high efficiency appears. With increase of the concentration of the tetracene the intensity of the tetracene fluorescence increases and that of the anthracene decreases. A similar process takes place when tetracene is added to naphthalene, or anthracene to naphthalene, etc. The emission of the impurity is said to take place by means of a transfer of the absorbed energy of radiation from the matrix molecules to the impurity molecules, and a nocessary condition for this is that the fluorescence of the impurity molecules should lie at longer wavelengths than that of the matrix. The energy-transfer process in solids has most often been studied in systems of the polyacenes and related molecules. A guide to the literature connected with the process entitled "Energy Transfer in Polyacene Solid Solutions" has recently been compiled by F. R. Lipsett (pp. ii +64 . Ottawa : National Research Council, 1957. 50 cents). It is divided into six sections, dealing respectively 